
3 Research Square
Preprints are preliminary reports that have not undergone peer review.
They should not be considered conclusive, used to inform clinical practice, or referenced by the media as validated information.

\title{
The Effect of Exercise Training, IMT and FES on Diastolic Function, Exercise Capacity and Quality of Life in Patients With Heart Failure With Preserved Ejection Fraction: a Systematic Review and Meta-analysis
}

\author{
Chenchen Zhuang \\ Lanzhou University Second Hospital \\ Xufei Luo \\ Lanzhou University \\ Qiongying Wang \\ Lanzhou University Second Hospital \\ Shipeng Li \\ Lanzhou University Second Hospital \\ Xiaofang Zhang \\ Lanzhou University Second Hospital \\ Wenjuan Wang \\ Lanzhou University Second Hospital \\ Runmin Sun \\ Lanzhou University Second Hospital \\ Ke Huang \\ Lanzhou University \\ Jing Yu ( $\nabla$ ery_jyu@lzu.edu.cn ) \\ Lanzhou University Second Hospital
}

\section{Research}

Keywords: functional electrical stimulation, inspiratory muscle training, exercise training, diastolic function, exercise tolerance, meta-analysis

Posted Date: February 24th, 2021

DOI: https://doi.org/10.21203/rs.3.rs-241175/v1

License: @ (i) This work is licensed under a Creative Commons Attribution 4.0 International License. Read Full License 


\section{Abstract}

Background: We aimed to better understand the effects of two exercise training interventions [endurance training and a combination of endurance and resistance training (combined exercise)] and two physiotherapies [functional electrical stimulation (FES) and inspiratory muscle training (IMT)] on diastolic function, exercise performance and quality of life (QoL) in heart failure with preserved ejection fraction (HFpEF) patients.

Methods: Cochrane Library, EMBASE and MEDLINE via PubMed for randomized controlled trials were searched from their inception to May 2020. The methodological quality was assessed using the Physiotherapy Evidence Database sacle. All analyses were used by STATA.

Results: A total of 14 articles on 13 trials were included in this meta-analysis with $673 \mathrm{HFpEF}$ patients. The pooling revealed that peak oxygen uptake was improved by endurance training [MD (95\% Cl): $\left.1.89 \mathrm{ml} . \mathrm{kg}^{-1} \cdot \mathrm{min}^{-1}(1.32,2.46), \mathrm{P}<0.001\right]$, FES [MD $\left.(95 \% \mathrm{Cl}): 2.28 \mathrm{ml}^{\mathrm{kgg}}{ }^{-1} . \mathrm{min}^{-1}(0.92,3.65), \mathrm{P}=0.001\right]$ and IMT [MD (95\% Cl): $\left.2.72 \mathrm{ml} \cdot \mathrm{kg}^{-1} \cdot \mathrm{min}^{-1}(1.44,3.99), \mathrm{P}<0.001\right]$. Similar results were observed for 6-minute walk test and QoL. Besides, endurance training increased arterial venous oxygen difference [MD $(95 \% \mathrm{Cl}): 1.41(0.09,2.74), \mathrm{P}=0.036]$. Combined exercise was beneficial to the ratio of peak early to late diastolic mitral inflow velocities [MD $(95 \% \mathrm{Cl}):-2.90(-4.97,-0.83), \mathrm{P}=0.006]$ and the early diastolic mitral annual velocity $[\mathrm{MD}(95 \% \mathrm{Cl}): 1.40(0.68,2.12), \mathrm{P}=0.006]$. IMT improved ventilation/carbon dioxide ratio slope [MD (95\% Cl): $\left.-3.36 \mathrm{ml}^{\circ} \mathrm{kg}^{-1} \cdot \mathrm{min}^{-1}(-6.17,-0.54), \mathrm{P}=0.019\right]$.

Conclusions: FES and IMT may be therapeutic options to improve functional capacity and QoL in HFpEF patients, and the outcomes are similar to endurance training. Combined exercise tends to improve diastolic function in HFpEF patients.

\section{Background}

Heart failure with preserved ejection fraction (HFpEF) comes about nearly half of heart failure patients in the community, and the mortality and morbidity are high $[1,2]$. Exercise intolerance is an important feature of $\mathrm{HFpEF}$, measured objectively as peak oxygen uptake $\left(\mathrm{peak} \mathrm{VO}_{2}\right)$ and quality of life $(\mathrm{Q} o \mathrm{~L})$ [3]. Besides one of the mechanisms underlying exercise intolerance has been identified by left ventricular (LV) diastolic function [4]. However, the established neurohormonal-based therapies, used for treating heart failure with reduced ejection fraction (HFrEF), has failed to improve exercise intolerance, provide favorable clinical outcomes and reduce primary endpoints for HFpEF [5].

Exercise training appears to be a promising evidence-based strategy to improve exercise intolerance in HFpEF patients [6]. In current studies, exercise training has consistently been shown to produce clinically meaningful increase in exercise capacity and a reduction in symptoms [7, 8]. However, the previous metaanalyses hold inconsistent opinions on diastolic function in HFpEF patients experiencing exercise training [8-10] due partly to failed to assess the different modalities of exercise training. Thus, we tried to evaluate the effect of different types of exercise training [(endurance, resistance, and a combination of these (combined exercise)] on diastolic function, exercise performance and QoL in patients with HFpEF.

Clinicians should recommend a 30 minutes per day of exercise training tailored to the abilities and resources are particular to each patient and should monitor compliance and address barriers to exercise training in ongoing follow-up [11, 12]. Moreover, HFpEF is often elderly and has many chronic symptoms, their adherence of exercise training remains well below the recommended levels [13]. Therefore, other physical therapy should be carried out to relieve the symptoms of HFpEF.

At present, physiotherapies mainly included inspiratory muscle training (IMT) [14] and functional electrical stimulation (FES) [15], which have been found to improve exercise capacity and QoL in $\operatorname{HFrEF}[15,16]$. IMT involves exercising the diaphragm-based muscles with inspiratory function, which improves muscle endurance and strength, functional capacity, and ventilator response to exercise and promote the recovery of motor ability [17]. The previous studies have reported that the effect of IMT on patients with heart failure (HF), including improving inspiratory muscle strength, peak $\mathrm{VO}_{2}, \mathrm{QoL}_{\mathrm{L}}$ and reduced dyspnea. The other physiotherapy involves the application of FES. FES, a neuromuscular stimulation, delivers in a specific recruitment pattern for performing a muscular movement necessary for exercise [15]. Electrically stimulated muscular contraction of lower limb muscles is safe and efficacious to improve the symptoms in chronic HF patients $[18,19]$. Moreover, FES elicits benefits in endothelial function, emotional stress and QoL in patients with moderate to severe chronic HF $[18,20]$. Notably, the potential benefits from IMT and FES implementation in HFpEF patients may not only be limited in patients unable to undergo exercise training, but also may be expanded in the general HFpEF population.

Despite the above promising data, there has so far been no published meta-analysis to evaluate the impact of IMT and FES modalities on exercise tolerance in patients with HFpEF. Therefore, the present meta-analysis is the first to investigate the effects of different modalities of exercise training (endurance training and combined exercise) and physiotherapies (FES and IMT) on diastolic function and exercise intolerance in HFpEF patients. It should be notable that no trials of separate resistance training meet the inclusion criteria in patients with HFpEF.

\section{Methods}

The present study was approved by the Ethics Committee Board of Lanzhou University Second Hospital (D2019-098) and conducted in accordance with the Preferred Reporting Items for Systematic Reviews and Meta-Analyses (PRISMA) [21].

\section{Patients and public involvement}

This is a meta-analysis based on study-level data and no individual-level data were involved in the study or defining the research question or outcome measures.

\section{Search strategy}


Studies on the effect of physical therapy in HFpEF patients published until May 31, 2020 were searched by Cochrane Library, EMBASE and MEDLINE via PubMed. We used a mix of medical subject heading (MeSH) and keywords including exercise training, aerobic exercise, endurance training, combined training, inspiratory muscle training, functional electrical stimulation, and heart failure with preserved ejection fraction. A manual search of the list of references of all identified studies and review articles was performed for additional relevant studies.

\section{Study selection}

Inclusion criteria included the following: (1) published as randomized controlled trials (RCTs). (2) Patients (aged $\geq 18$ years) with HFpEF were considered. (3) Patients (physical therapy group) undergoing endurance exercise, combined exercise, FES and IMT were considered. (4) Control group (non-intervention group) included those with a sedentary life style and those having some life-style education.

Articles that failed to meet the inclusion criteria were removed, including reviews, animal studies, non-RCTs, non-English language, those investigations with only healthy participants, and intervention durations with less than 4 weeks. Exercise was defined to allow for inclusion of a broad range of structured physical activities and included endurance, resistance, combined training (endurance and resistance). Additionally, physiotherapies of FES and IMT were included in the definition of exercise for the purpose of this meta-analysis.

\section{Main outcomes}

Primary outcomes of this study were exercise capacity measured by [peak $\mathrm{VO}_{2}$ and 6-minute walk test (6MWT)], QoL measured by [Minnesota Living with Heart Failure Questionnaire (MLHFQ) total score]. Secondary outcomes were evaluated by diastolic function [measured by the ratio of peak early to late diastolic mitral inflow velocities (E/A), the ratio of early diastolic mitral inflow to annular velocities (E/e'), and the early diastolic mitral annular velocity ( $\left.\mathrm{e}^{\prime}\right)$ ], ventilation/carbon dioxide ratio slope $\left(\mathrm{VE} / \mathrm{VCO}_{2}\right)$ slope and arterial-venous oxygen difference $\left(\mathrm{A}-\mathrm{VO}_{2}\right.$ Diff).

\section{Data extraction}

The following information was summarized: study characteristics (e.g. authors, year of publication and country), participant characteristics (e.g. age and sample size of different group), study methods/design, period of exercise intervention and outcomes. Full-text articles were retrieved for all title-abstracts that met the eligibility by two reviewers (Chenchen Zhuang and Xufei Luo), and a consensus reached by consulting a third reviewer (Qiongying Wang) if required.

\section{Risk of Bias}

We evaluated the risk of bias for inclusion in this meta-analysis by the Physiotherapy Evidence Database (PEDro) scale [22]. The methodological quality of each article was independently assessed by the two reviewers using a total scale, including eligibility criteria, point estimates and variability, between-group comparisons, intention-to-treat analysis, adequate follow-up, blinded assessors, blinded subjects, blinded therapists, baseline comparability, concealed allocation and random allocation. When a disagreement occurred, a third reviewer was consulted.

\section{Data synthesis and analysis}

For each outcome, the effect size in our study was assessed by the baseline to follow-up change. If the outcome was measured on the same scale, we used weighted mean difference (MD) and $95 \%$ confidence intervals $(\mathrm{Cl})$. When the $P$ statistic was lower than $30 \%$ and $\mathrm{P}<0.10$, a fixed-effect model was used; otherwise, a random effects model was used. We assessed publication bias through Egger's regression test. Subgroup analysis was conducted to investigate the effect of different modalities of physical therapies on diastolic function, QoL and exercise performance. Furthermore, to account for differences in the functional capacity and QoL between intervention and control groups, we conducted meta-regression analysis for these outcomes (change in peak $\mathrm{VO}_{2}$ and change in MLWHF total score). All analyses were based on intention-to-treat data. All analyses were used by STATA version 14.0 (Stata Corporation, College Station, TX).

\section{Results}

\section{Included studies}

The flow chart is shown in Figure 1, screening identified 129 potential reports. After removal of duplicates, 152 records remained. After going through the titles and abstracts, 117 studies were excluded. Then 21 were excluded because they did not report HFpEF. 2 articles were identified as double publication, thus were rated as one study $[23,24]$. Ultimately, 11 RCTs on conventional physical therapies [7, 23-32] and 3 RCTs on non-conventional physical therapies were included in this meta-analysis $[18,33,34]$.

\section{Characteristics of studies}

The basic characteristics of each study were summarized in Table 1. A total of 14 articles on 13 trials including $673 \mathrm{HFpEF}$ patients were included in the present meta-analysis. One of all RCTs included not only FES intervention, but also IMT intervention [33]. Our original intention was to evaluate the effects of physiotherapy (FES and IMT) and exercise training (endurance training and combined exercise), respectively. The mean age of participants ranged from 60.5 to 75 years, and the proportion of women ranged from 35.6 to $100 \%$. Primary outcomes of the study were exercise capacity (measured by peak $\mathrm{VO}_{2}$ and 6MWT), QoL (measured by MLHFQ total score). Secondary outcomes that were also evaluated in the study included diastolic function (measured by E/A, E/e' and $\left.\mathrm{e}^{\prime}\right), \mathrm{VE} / \mathrm{VCO}_{2}$ slope and $\mathrm{A}-\mathrm{VO}_{2}$ Diff.

\section{Quality assessment}


The quality of included RCTs is presented in Table 2. In none of the studies was there objective evidence of imbalance in baseline characteristics between the intervention and control groups. The moderate risk of bias was due to inadequate blinding of participants and therapists, allocation concealment and intention-to-treat methodologies. Some may be contributed to insufficient reporting rather than inherent design weakness.

\section{Diastolic function}

Eight trials with 416 patients reported on $\mathrm{E} / \mathrm{A}$ (Fig. 2. A). The heterogeneity was small $(R=0 \%, P=0.606)$, using a fixed-effect model. E/A was no change by endurance training [MD $(95 \% \mathrm{Cl}): 0.03(-0.03,0.09), \mathrm{P}=0.307]$, combined exercise [MD (95\% Cl): $-0.03(-0.17,0.11), \mathrm{P}=0.678]$, and FES [MD (95\% Cl): -0.12 $(-0.29,0.05), P=0.162]$.

Ten trials with 416 patients reported on E/e' (Fig. 2. B). There was a statistical heterogeneity $(R=43.1 \%, P=0.071)$, using a random-effect model. E/e' was improved by combined exercise with one included study [MD $(95 \% \mathrm{Cl}):-2.90(-4.97,-0.83), \mathrm{P}=0.006]$. There was no change in $\mathrm{E} / \mathrm{e}^{\prime}$ by endurance training [MD $(95 \% \mathrm{Cl}):-0.03(-2.83,2.78), \mathrm{P}=0.983]$, FES [MD $(95 \% \mathrm{Cl}):-2.16(-4.41,0.09), \mathrm{P}=0.060]$ and IMT [MD $(95 \% \mathrm{Cl}):-1.10(-4.56,2.36), \mathrm{P}=0.533]$.

Four trials with 215 patients reported on e' (Fig. 2. C). There was a statistical heterogeneity $(P=81.3 \%, P=0.001)$, using a random-effect model. e' was improved by combined exercise with one included study [MD (95\% Cl): $1.40(0.68,2.12), \mathrm{P}$ 0.001$]$. There was no change in e' by endurance training [MD $(95 \%$ CI): $-2.90(-4.97,-0.83), P=0.140]$ and IMT [MD $(95 \% \mathrm{Cl}): 0.30(-1.28,1.88), \mathrm{P}=0.709]$.

\section{Quality of life}

Thirteen trials with 560 patients reported on the MLHFQ total score (Fig. 3). The heterogeneity was small $(P=28.5 \%, P=0.158)$, using a fixed-effect model. The MLHFQ total score was improved by endurance training [MD (95\% Cl): $-9.13(-12.98,-5.28), \mathrm{P}<0.001], \mathrm{FES}$ [MD (95\% CI): -14.74 (-22.44, -7.08$), \mathrm{P}<0.001]$ and IMT [MD (95\% Cl): -11.49 (-20.08, -2.91), P = 0.009]. However, the MLHFQ total score was not significantly changed by combined exercise [MD (95\% Cl): -6.00 (-15.99, 3.99), $P=0.239]$. Meta-regression analysis showed no significant effect of exercise period, age and sex on the pooled $M D$ (exercise period: metaregression coefficient, $1.116 ; \mathrm{P}=0.574$; age: meta-regression coefficient, $-0.689 ; \mathrm{P}=0.800$; sex: meta-regression coefficient, $-0.523 ; \mathrm{P}=0.852$ ).

\section{Exercise performance}

Our meta-analysis could be performed for two functional capacity indicators: $6 \mathrm{MWT}$ and peak $\mathrm{VO}_{2}$; one exercise physiology parameter: $\mathrm{VE} / \mathrm{VCO} \mathrm{O}_{2}$ slope.

Eight trials with 411 patients reported on 6MWT (Fig. 4. A). The heterogeneity was small $(R=0.0 \%, P=0.560)$, using a fixed-effect model. $6 \mathrm{MWT}$ was increased by endurance training [MD (95\% Cl): $38.79 \mathrm{~m}(19.97,57.61), \mathrm{P}<0.001]$ and FES [MD (95\% Cl): $52.77 \mathrm{~m}(30.61,74.93), \mathrm{P}<0.001]$. However, there was no change after IMT [MD (95\% Cl): $84.00 \mathrm{~m}(-31.73,199.73), \mathrm{P}=0.155]$ and combined exercise [MD $(95 \% \mathrm{Cl}): 7.00 \mathrm{~m}(-37.61,51.61), \mathrm{P}=0.758]$.

Thirteen trials with 411 patients reported on peak $\mathrm{VO}_{2}$ (Fig. 4. B). The heterogeneity was small $(R=0.0 \%, P=0.739)$, using a fixed-effect model. Peak VO $\mathrm{O}_{2}$ was improved by endurance training [MD (95\% Cl): $\left.1.89 \mathrm{ml}^{\mathrm{kgg}}{ }^{-1} \cdot \mathrm{min}^{-1}(1.32,2.46), \mathrm{P}<0.001\right]$, FES [MD (95\% Cl): $\left.2.28 \mathrm{ml}^{\mathrm{kgg}}{ }^{-1} \cdot \mathrm{min}^{-1}(0.92,3.65), \mathrm{P}=0.001\right], \mathrm{IMT}[\mathrm{MD}$ $\left.(95 \% \mathrm{Cl}): 2.72 \mathrm{ml} \cdot \mathrm{kg}^{-1} \cdot \mathrm{min}^{-1}(1.44,3.99), \mathrm{P}<0.001\right]$ and combined exercise [MD (95\% Cl): $\left.3.30 \mathrm{ml}^{\mathrm{k}} \mathrm{kg}^{-1} \cdot \mathrm{min}^{-1}(0.44,6.16), \mathrm{P}=0.024\right]$. Meta-regression analysis showed no significant effect of exercise period, age and sex on the pooled MD (age: meta-regression coefficient, 0.007; $P=0.989 ;$ sex: meta-regression coefficient, 0.010; $\mathrm{P}=0.826$ ). However, exercise period affected the change of peak $\mathrm{VO}_{2}$ (meta-regression coefficient, $-0.736 ; \mathrm{P}=0.036$ ).

Eleven trials with 502 patients reported on $\mathrm{VE} / \mathrm{VCO}_{2}$ slope (Fig. 4. C). There was a statistical heterogeneity $(R=39.9 \%, \mathrm{P}=0.083)$, using a random-effect model. VE/ $\mathrm{VCO}_{2}$ slope was improved by IMT [MD $\left.(95 \% \mathrm{Cl}):-3.36(-6.17,-0.54), \mathrm{P}=0.019\right]$. No significant difference was found after endurance training $[\mathrm{MD}$ $(95 \% \mathrm{Cl}):-1.04(-2.73,0.64), \mathrm{P}=0.226]$, FES [MD (95\% Cl): 0.35 (-2.67, 3.37), $\mathrm{P}=0.819]$, and combined exercise [MD (95\% Cl): $-1.90(-4.44,0.64), \mathrm{P}=0.142]$. Smart et al. [26] may be the source of heterogeneity due to the small sample.

\section{$\mathrm{A}-\mathrm{VO}_{2}$ Diff}

Two trials with 99 patients reported on $\mathrm{A}-\mathrm{VO}_{2}$ Diff (Fig. 5). The two trials were both belonged to endurance training. The heterogeneity was small $(R=0.0 \%, \mathrm{P}=$ 0.462). $\mathrm{A}-\mathrm{VO}_{2}$ Diff was improved by endurance training [MD $\left.(95 \% \mathrm{Cl}): 1.41(0.09,2.74), \mathrm{P}=0.036\right]$.

\section{Discussion}

The present meta-analysis summarized data from 14 on 13 RCTs that examined the effects of two exercise training interventions and two physiotherapies on diastolic function, exercise performance and QoL in HFpEF patients. FES and IMT improved exercise performance and QoL, and the outcomes were similar to endurance training, but the change of diastolic function on FES, IMT and endurance training was not found. Notably, combined exercise has a potential to improve diastolic function on HFpEF patients.

The previous studies have focused primarily on overall exercise training rather than the different types of exercise training. The meta-analysis of Gomes-Neto et al. [35] only conducted endurance training and failed to represent other exercise modality. They showed that exercise training improved peak $\mathrm{VO}_{2}$ and $\mathrm{QoL}$, but exercise training failed to improve diastolic function. The meta-analysis of Fukuta et al. [10] showed that exercise training improved exercise capacity in HFpEF patients. But a methodological limitation was the combination of results from Fukuta et al. that investigated endurance training and combined exercise. Besides, The previous meta-analyses held inconsistent opinions on diastolic function in HFpEF patients during exercise training [8-10]. Thus, the present meta-analysis compensated for the weakness of the previous studies. 
The present meta-analysis observed that functional capacity indicators (peak $\mathrm{VO}_{2}$ and $6 \mathrm{MWT}$ ) and QoL were improved by FES and IMT, as well as exercise training. The positive result of QoL in endurance training or combined exercise is in accordance with the previous meta-analyses [8-10]. In addition, the evaluation of $\mathrm{A}-\mathrm{VO}_{2}$ Diff is only reported by endurance training, showing a positive result. The peak $\mathrm{VO}_{2}$ may affect oxygen delivery and/or utilization via cardiac, vascular and skeletal muscle function [36-39]. Besides, the active skeletal muscle is the major reason to induce the augment of peak $\mathrm{VO}_{2}$ in $\mathrm{HFpEF}$ patients, including oxidative enzyme activity, capillary density and mitochondrial density [29].

Our findings showed that combined exercise improved E/e' and e', failed to improve E/A, whereas, endurance training, FES and IMT failed to improve diastolic function. Smart et al. [26] suggested that 16-week endurance training may not be sufficient to elicit alteration in myocardial properties. Meanwhile, Fujimoto et al. [40] reported that 1-year endurance training had little effect on LV compliance and cardiovascular stiffness in HFpEF patients. Conversely, Edelmann et al. [23] reported that combined exercise improved diastolic function, as evidenced by a significant reduction in E/e' and e'. Diastolic function may be impacted by peripheral determinants (e.g. oxygen use by skeletal muscle, body mass index, etc), not by central determinants (e.g. E/A, E/E', etc) [41]. In response to exercise training, cardiac relaxation may be compounded by abnormalities in skeletal muscle oxygen use, which augments cardiac output, and flow into a small, stiff and slowly relaxing heart $[42,43]$. Thus, the different results of diastolic function between combined exercise and endurance training may be induced by resistance training, which adds muscle bulk to peripheral muscles and increases bone mass.

FES improves selected muscle in a coordinated manner and the aerobic oxidative capacity, which results in a functional pattern such as walking, cycling, or rowing [44-48]. FES seems to act primarily on peripheral vascular system, whereas its effects may be indirect on central diastolic function. Moreover, IMT improve pathophysiologic manifestations of HF via breathing against an external inspiratory load. Prior literature has reported improvement in exercise capacity, functional autonomy, diaphragmatic thickness and mobility, and cardiac autonomic control.

Our result showed that IMT significantly improved $\mathrm{VE} / \mathrm{VCO}_{2}$ slope, but no positive effect was found in other types of physical therapy. Various studies of $\mathrm{HF}$ patients have shown that selective respiratory muscle training improved submaximal and maximal exercise capacity and/or perceived dyspnea during daily living activities in HFrEF patients [17, 49-54]. Interestingly, the magnitude of outcome in HFpEF patients following IMT intervention was similar [17, 54] or even stronger $[49,51,52]$ compared to other important trials aiming to evaluate the effect of IMT in HFrEF patients. The development of diaphragmatic fatigue is a delay, leading to a reduction in the recruitment of accessory respiratory muscles, and an improved ventilatory efficiency $[53,55]$.

\section{Strengths and limitation}

Although this study shows that FES and IMT may be effective for HFpEF, which may be an compensate rehabilitation to patients unable to experience exercise training. Moreover, combined exercise exhibits a positive effect on diastolic function

All included studies were RCTs, and none were rated as poor in methodological quality according to the PEDro score, which suggests that the data presented are reliable. However, some included RCTs have small sample sizes, and according to the subgroup analysis of the different modalities of physical therapy on cardiac function, QoL and exercise performance. Second, there are only two studies reported combined exercise, however, they share one set of date using different results $[23,24]$.

Further research is needed to pay more attention to the mechanism of hemodynamics and muscle function on HFpEF patients experiencing physical therapy. Besides, larger scale, good quality RCTs are needed for further investigating the effect of combined exercise, FES and IMT on patients with HFpEF.

\section{Conclusions}

In conclusion, our meta-analysis suggests that FES and IMT tend to a positive effect to HFpEF patients, the positive outcomes may be superior to exercise training. Besides, IMT tends to improve VE/ $\mathrm{VCO}_{2}$ slope. FES and IMT are surrogate rehabilitation for patients unable of exercise training.

\section{Declarations}

\section{Consent for publication}

The present study was approved by the Ethics Committee Board of Lanzhou University Second Hospital (D2019-098).

\section{Competing interests}

No potential conflict of interest was reported by the authors.

\section{Funding}

This work was supported by the National Natural Science Foundation of China (81960086).

\section{Author Contributions}

1. Conception and design: Chenchen Zhuang and Jing Yu

2. Administrative support: Lanzhou University Second Hospital

3. Provision of study: Xufei Luo

4. Collection and assembly of data: Chenchen Zhuang and Xufei Luo 
5. Data analysis and interpretation: Chenchen Zhuang and Xufei Luo

6. Manuscript writing: All authors

7. Final approval of manuscript: All authors

\section{Acknowledgements}

We acknowledge Prof. Yuanhang Cheng (City University of Hong Kong) for constructive suggestions. Extremely careful and thoughtful reviews by Associate Editor and Reviewer improved this manuscript greatly.

\section{References}

1. Lewis EF, Claggett B, Shah AM, Liu J, Shah SJ, Anand I, et al. Racial Differences in Characteristics and Outcomes of Patients With Heart Failure and Preserved Ejection Fraction in the Treatment of Preserved Cardiac Function Heart Failure Trial. Circulation Heart failure. 2018;11(3):e004457.

2. Zacharias M, Joffe S, Konadu E, Meyer T, Kiernan M, Lessard D, et al. Clinical epidemiology of heart failure with preserved ejection fraction (HFpEF) in comparatively young hospitalized patients. International journal of cardiology. 2016;202:918-21.

3. Haykowsky M, Brubaker P, Kitzman D. Role of physical training in heart failure with preserved ejection fraction. Current heart failure reports. 2012;9(2):1016.

4. Chioncel O, Lainscak M, Seferovic PM, Anker SD, Crespo-Leiro MG, Harjola VP, et al. Epidemiology and one-year outcomes in patients with chronic heart failure and preserved, mid-range and reduced ejection fraction: an analysis of the ESC Heart Failure Long-Term Registry. European journal of heart failure. 2017;19(12):1574-85.

5. Kaila K, Haykowsky MJ, Thompson RB, Paterson DI. Heart failure with preserved ejection fraction in the elderly: scope of the problem. Heart failure reviews. 2012;17(4-5):555-62.

6. Dieberg G, Ismail H, Giallauria F, Smart NA. Clinical outcomes and cardiovascular responses to exercise training in heart failure patients with preserved ejection fraction: a systematic review and meta-analysis. Journal of applied physiology (Bethesda, Md : 1985). 2015;119(6):726-33.

7. Kitzman DW, Brubaker P, Morgan T, Haykowsky M, Hundley G, Kraus WE, et al. Effect of Caloric Restriction or Aerobic Exercise Training on Peak Oxygen Consumption and Quality of Life in Obese Older Patients With Heart Failure With Preserved Ejection Fraction: A Randomized Clinical Trial. Jama. 2016;315(1):36-46.

8. Pandey A, Parashar A, Kumbhani D, Agarwal S, Garg J, Kitzman D, et al. Exercise training in patients with heart failure and preserved ejection fraction: meta-analysis of randomized control trials. Circulation Heart failure. 2015;8(1):33-40.

9. Chan E, Giallauria F, Vigorito C, Smart NA. Exercise training in heart failure patients with preserved ejection fraction: a systematic review and metaanalysis. Monaldi archives for chest disease = Archivio Monaldi per le malattie del torace. 2016;86(1-2):759.

10. Fukuta H, Goto T, Wakami K, Kamiya T, Ohte N. Effects of exercise training on cardiac function, exercise capacity, and quality of life in heart failure with preserved ejection fraction: a meta-analysis of randomized controlled trials. Heart Fail Rev. 2019;24(4):535-47.

11. Yancy CW, Jessup M, Bozkurt B, Butler J, Casey DE, Jr., Drazner MH, et al. 2013 ACCF/AHA guideline for the management of heart failure: a report of the American College of Cardiology Foundation/American Heart Association Task Force on practice guidelines. Circulation. 2013;128(16):e240-327.

12. Ponikowski P, Voors AA, Anker SD, Bueno H, Cleland JGF, Coats AJS, et al. 2016 ESC Guidelines for the Diagnosis and Treatment of Acute and Chronic Heart Failure. Revista espanola de cardiologia (English ed). 2016;69(12):1167.

13. Mediano MFF, Leifer ES, Cooper LS, Keteyian SJ, Kraus WE, Mentz RJ, et al. Influence of Baseline Physical Activity Level on Exercise Training Response and Clinical Outcomes in Heart Failure: The HF-ACTION Trial. JACC Heart failure. 2018;6(12):1011-9.

14. Tong TK, McConnell AK, Lin H, Nie J, Zhang H, Wang J. "Functional" Inspiratory and Core Muscle Training Enhances Running Performance and Economy. J Strength Cond Res. 2016;30(10):2942-51.

15. Smart NA, Dieberg G, Giallauria F. Functional electrical stimulation for chronic heart failure: a meta-analysis. International journal of cardiology. 2013;167(1):80-6.

16. Smart NA, Giallauria F, Dieberg G. Efficacy of inspiratory muscle training in chronic heart failure patients: a systematic review and meta-analysis. International journal of cardiology. 2013;167(4):1502-7.

17. Lin SJ, McElfresh J, Hall B, Bloom R, Farrell K. Inspiratory muscle training in patients with heart failure: a systematic review. Cardiopulmonary physical therapy journal. 2012;23(3):29-36.

18. Karavidas A, Driva M, Parissis JT, Farmakis D, Mantzaraki V, Varounis C, et al. Functional electrical stimulation of peripheral muscles improves endothelial function and clinical and emotional status in heart failure patients with preserved left ventricular ejection fraction. American heart journal.

2013;166(4):760-7.

19. Parissis J, Karavidas A, Farmakis D, Papoutsidakis N, Matzaraki V, Arapi S, et al. Efficacy and safety of functional electrical stimulation of lower limb muscles in elderly patients with chronic heart failure: A pilot study. European journal of preventive cardiology. 2015;22(7):831-6.

20. Deftereos S, Giannopoulos G, Raisakis K, Kossyvakis C, Kaoukis A, Driva M, et al. Comparison of muscle functional electrical stimulation to conventional bicycle exercise on endothelium and functional status indices in patients with heart failure. The American journal of cardiology. 2010;106(11):1621-5.

21. Moher D, Liberati A, Tetzlaff J, Altman DG. Preferred reporting items for systematic reviews and meta-analyses: the PRISMA statement. PLoS medicine. 2009;6(7):e1000097. 
22. Higgins JP, Altman DG, Gøtzsche PC, Jüni P, Moher D, Oxman AD, et al. The Cochrane Collaboration's tool for assessing risk of bias in randomised trials. Bmj. 2011;343:d5928.

23. Edelmann F, Gelbrich G, Düngen HD, Fröhling S, Wachter R, Stahrenberg R, et al. Exercise training improves exercise capacity and diastolic function in patients with heart failure with preserved ejection fraction: results of the Ex-DHF (Exercise training in Diastolic Heart Failure) pilot study. Journal of the American College of Cardiology. 2011;58(17):1780-91.

24. Nolte K, Herrmann-Lingen C, Wachter R, Gelbrich G, Düngen HD, Duvinage A, et al. Effects of exercise training on different quality of life dimensions in heart failure with preserved ejection fraction: the Ex-DHF-P trial. European journal of preventive cardiology. 2015;22(5):582-93.

25. Kitzman DW, Brubaker PH, Morgan TM, Stewart KP, Little WC. Exercise training in older patients with heart failure and preserved ejection fraction: a randomized, controlled, single-blind trial. Circulation Heart failure. 2010;3(6):659-67.

26. Smart NA, Haluska B, Jeffriess L, Leung D. Exercise training in heart failure with preserved systolic function: a randomized controlled trial of the effects on cardiac function and functional capacity. Congestive heart failure (Greenwich, Conn). 2012;18(6):295-301.

27. Maldonado-Martín S, Brubaker PH, Eggebeen J, Stewart KP, Kitzman DW. Association Between 6-Minute Walk Test Distance and Objective Variables of Functional Capacity After Exercise Training in Elderly Heart Failure Patients With Preserved Ejection Fraction: A Randomized Exercise Trial. Archives of physical medicine and rehabilitation. 2017;98(3):600-3.

28. Fu TC, Yang NI, Wang CH, Cherng WJ, Chou SL, Pan TL, et al. Aerobic Interval Training Elicits Different Hemodynamic Adaptations Between Heart Failure Patients with Preserved and Reduced Ejection Fraction. American journal of physical medicine \& rehabilitation. 2016;95(1):15-27.

29. Kitzman DW, Brubaker PH, Herrington DM, Morgan TM, Stewart KP, Hundley WG, et al. Effect of endurance exercise training on endothelial function and arterial stiffness in older patients with heart failure and preserved ejection fraction: a randomized, controlled, single-blind trial. Journal of the American College of Cardiology. 2013;62(7):584-92.

30. Gary RA, Sueta CA, Dougherty M, Rosenberg B, Cheek D, Preisser J, et al. Home-based exercise improves functional performance and quality of life in women with diastolic heart failure. Heart \& lung : the journal of critical care. 2004;33(4):210-8.

31. Alves AJ, Ribeiro F, Goldhammer E, Rivlin Y, Rosenschein U, Viana JL, et al. Exercise training improves diastolic function in heart failure patients. Medicine and science in sports and exercise. 2012;44(5):776-85.

32. Haykowsky MJ, Brubaker PH, Stewart KP, Morgan TM, Eggebeen J, Kitzman DW. Effect of endurance training on the determinants of peak exercise oxygen consumption in elderly patients with stable compensated heart failure and preserved ejection fraction. Journal of the American College of Cardiology. 2012;60(2):120-8.

33. Palau P, Domínguez E, López L, Ramón JM, Heredia R, González J, et al. Inspiratory Muscle Training and Functional Electrical Stimulation for Treatment of Heart Failure With Preserved Ejection Fraction: The TRAINING-HF Trial. Revista espanola de cardiologia (English ed). 2019;72(4):288-97.

34. Palau P, Domínguez E, Núñez E, Schmid JP, Vergara P, Ramón JM, et al. Effects of inspiratory muscle training in patients with heart failure with preserved ejection fraction. European journal of preventive cardiology. 2014;21(12):1465-73.

35. Gomes-Neto M, Durães AR, Conceição LSR, Roever L, Liu T, Tse G, et al. Effect of Aerobic Exercise on Peak Oxygen Consumption, VE/VCO(2) Slope, and Health-Related Quality of Life in Patients with Heart Failure with Preserved Left Ventricular Ejection Fraction: a Systematic Review and Meta-Analysis. Current atherosclerosis reports. 2019;21(11):45.

36. Rundqvist L, Engvall J, Faresjö M, Blomstrand P. Left ventricular diastolic function is enhanced after peak exercise in endurance-trained adolescents as well as in their non-trained controls. Clinical physiology and functional imaging. 2018.

37. Studer Bruengger AA, Kaufmann BA, Buser M, Hoffmann M, Bader F, Bernheim AM. Diastolic stress echocardiography in the young: a study in nonathletic and endurance-trained healthy subjects. Journal of the American Society of Echocardiography : official publication of the American Society of Echocardiography. 2014;27(10):1053-9.

38. Kitzman DW, Little WC, Brubaker PH, Anderson RT, Hundley WG, Marburger CT, et al. Pathophysiological characterization of isolated diastolic heart failure in comparison to systolic heart failure. Jama. 2002;288(17):2144-50.

39. La Gerche A, Burns AT, Taylor AJ, Macisaac Al, Heidbüchel H, Prior DL. Maximal oxygen consumption is best predicted by measures of cardiac size rather than function in healthy adults. European journal of applied physiology. 2012;112(6):2139-47.

40. Fujimoto N, Prasad A, Hastings JL, Bhella PS, Shibata S, Palmer D, et al. Cardiovascular effects of 1 year of progressive endurance exercise training in patients with heart failure with preserved ejection fraction. American heart journal. 2012;164(6):869-77.

41. Wolsk E, Kaye D, Komtebedde J, Shah SJ, Borlaug BA, Burkhoff D, et al. Central and Peripheral Determinants of Exercise Capacity in Heart Failure Patients With Preserved Ejection Fraction. JACC Heart failure. 2019;7(4):321-32.

42. Sullivan MJ, Knight JD, Higginbotham MB, Cobb FR. Relation between central and peripheral hemodynamics during exercise in patients with chronic heart failure. Muscle blood flow is reduced with maintenance of arterial perfusion pressure. Circulation. 1989;80(4):769-81.

43. Borlaug BA, Olson TP, Lam CS, Flood KS, Lerman A, Johnson BD, et al. Global cardiovascular reserve dysfunction in heart failure with preserved ejection fraction. Journal of the American College of Cardiology. 2010;56(11):845-54.

44. Kim KM, Croy T, Hertel J, Saliba S. Effects of neuromuscular electrical stimulation after anterior cruciate ligament reconstruction on quadriceps strength, function, and patient-oriented outcomes: a systematic review. The Journal of orthopaedic and sports physical therapy. 2010;40(7):383-91.

45. Kern H, Barberi L, Löfler S, Sbardella S, Burggraf S, Fruhmann H, et al. Electrical stimulation counteracts muscle decline in seniors. Frontiers in aging neuroscience. 2014;6:189.

46. Pozehl B, Duncan K, Hertzog M. The effects of exercise training on fatigue and dyspnea in heart failure. European journal of cardiovascular nursing : journal of the Working Group on Cardiovascular Nursing of the European Society of Cardiology. 2008;7(2):127-32.

Page $7 / 16$ 
47. Little WC, Kitzman DW, Cheng CP. Diastolic dysfunction as a cause of exercise intolerance. Heart failure reviews. 2000;5(4):301-6.

48. Saitoh M, Dos Santos MR, Anker M, Anker SD, von Haehling S, Springer J. Neuromuscular electrical stimulation for muscle wasting in heart failure patients. International journal of cardiology. 2016;225:200-5.

49. Mancini DM, Henson D, La Manca J, Donchez L, Levine S. Benefit of selective respiratory muscle training on exercise capacity in patients with chronic congestive heart failure. Circulation. 1995;91(2):320-9.

50. Johnson PH, Cowley AJ, Kinnear WJ. A randomized controlled trial of inspiratory muscle training in stable chronic heart failure. European heart journal. 1998;19(8):1249-53.

51. Weiner P, Waizman J, Magadle R, Berar-Yanay N, Pelled B. The effect of specific inspiratory muscle training on the sensation of dyspnea and exercise tolerance in patients with congestive heart failure. Clinical cardiology. 1999;22(11):727-32.

52. Laoutaris I, Dritsas A, Brown MD, Manginas A, Alivizatos PA, Cokkinos DV. Inspiratory muscle training using an incremental endurance test alleviates dyspnea and improves functional status in patients with chronic heart failure. European journal of cardiovascular prevention and rehabilitation : official journal of the European Society of Cardiology, Working Groups on Epidemiology \& Prevention and Cardiac Rehabilitation and Exercise Physiology. 2004;11(6):489-96.

53. Dall'Ago P, Chiappa GR, Guths H, Stein R, Ribeiro JP. Inspiratory muscle training in patients with heart failure and inspiratory muscle weakness: a randomized trial. Journal of the American College of Cardiology. 2006;47(4):757-63.

54. Stein R, Chiappa GR, Güths H, Dall'Ago P, Ribeiro JP. Inspiratory muscle training improves oxygen uptake efficiency slope in patients with chronic heart failure. Journal of cardiopulmonary rehabilitation and prevention. 2009;29(6):392-5.

55. Illi SK, Held U, Frank I, Spengler CM. Effect of respiratory muscle training on exercise performance in healthy individuals: a systematic review and metaanalysis. Sports medicine (Auckland, NZ). 2012;42(8):707-24.

\section{Tables}


Table 1

Characteristics of the included studies

\begin{tabular}{|c|c|c|c|c|c|c|}
\hline Article, year & Country & $\begin{array}{l}\text { Study } \\
\text { sample }\end{array}$ & $\begin{array}{l}\text { Participants include in the } \\
\text { analysis }\end{array}$ & $\begin{array}{l}\text { Intervention/comparison } \\
\text { groups }\end{array}$ & Duration of trial period & Outcomes \\
\hline $\begin{array}{l}\text { Palau } \\
(2019)\end{array}$ & Spain & $\begin{array}{l}\text { NYHA } \\
\text { class } \\
\text { I-III } \\
\text { LVEF > } \\
50 \%\end{array}$ & $\begin{array}{l}\text { Total patients: } \mathrm{n}=28 \\
\text { G1: } \mathrm{n}=15,6 \text { males } / 9 \text { females, } \\
\text { mean age (SD): } 72(9) \\
\text { G2: } \mathrm{n}=13,4 \text { males } / 9 \text { females, } \\
\text { mean age (SD): } 75(9)\end{array}$ & $\begin{array}{l}\text { G1: FES } \\
\text { G2: Usual care }\end{array}$ & $\begin{array}{l}\text { Twice per week for } 12 \\
\text { weeks }\end{array}$ & $\begin{array}{l}\text { E/e', QoL, peak } \mathrm{VO}_{2}, \\
\mathrm{VE} / \mathrm{VCO}_{2} \text { slope }\end{array}$ \\
\hline $\begin{array}{l}\text { Palau } \\
(2019)\end{array}$ & Spain & $\begin{array}{l}\text { NYHA } \\
\text { class } \\
\text { I-III } \\
\text { LVEF > } \\
50 \%\end{array}$ & $\begin{array}{l}\text { Total patients: } \mathrm{n}=28 \\
\text { G1: } \mathrm{n}=15,7 \text { males } / 8 \text { females, } \\
\text { mean age (SD): } 75(10) \\
\text { G2: } n=13,4 \text { males } / 9 \text { females, } \\
\text { mean age (SD): } 75(9)\end{array}$ & $\begin{array}{l}\text { G1: IMT } \\
\text { G2: Usual care }\end{array}$ & $\begin{array}{l}\text { Twice per week for } 12 \\
\text { weeks }\end{array}$ & $\begin{array}{l}\text { E/e', QoL, peak } \mathrm{VO}_{2} \text {, } \\
\mathrm{VE} / \mathrm{VCO}_{2} \text { slope }\end{array}$ \\
\hline $\begin{array}{l}\text { Palau } \\
(2019)\end{array}$ & Spain & $\begin{array}{l}\text { NYHA } \\
\text { class } \\
\text { I-III } \\
\text { LVEF > } \\
50 \%\end{array}$ & $\begin{array}{l}\text { Total patients: } \mathrm{n}=28 \\
\text { G1: } \mathrm{n}=15,6 \text { males } / 9 \text { females, } \\
\text { mean age (SD): } 72(9) \\
\text { G2: } \mathrm{n}=13,4 \text { males } / 9 \text { females, } \\
\text { mean age (SD): } 75(9)\end{array}$ & $\begin{array}{l}\text { G1: FES } \\
\text { G2: Usual care }\end{array}$ & $\begin{array}{l}\text { Twice per week for } 24 \\
\text { weeks }\end{array}$ & $\begin{array}{l}\text { E/e', QoL, peak } \mathrm{VO}_{2} \text {, } \\
\mathrm{VE} / \mathrm{VCO}_{2} \text { slope }\end{array}$ \\
\hline $\begin{array}{l}\text { Palau } \\
(2019)\end{array}$ & Spain & $\begin{array}{l}\text { NYHA } \\
\text { class } \\
\text { I-III } \\
\text { LVEF > } \\
50 \%\end{array}$ & $\begin{array}{l}\text { Total patients: } \mathrm{n}=28 \\
\text { G1: } \mathrm{n}=15,7 \text { males } / 8 \text { females, } \\
\text { mean age (SD): } 75(10) \\
\text { G2: } \mathrm{n}=13,4 \text { males } / 9 \text { females, } \\
\text { mean age (SD): } 75(9)\end{array}$ & $\begin{array}{l}\text { G1: IMT } \\
\text { G2: Usual care }\end{array}$ & $\begin{array}{l}\text { Twice per week for } 24 \\
\text { weeks }\end{array}$ & $\begin{array}{l}\text { E/e', QoL, peak } \mathrm{VO}_{2} \text {, } \\
\mathrm{VE} / \mathrm{VCO}_{2} \text { slope }\end{array}$ \\
\hline $\begin{array}{l}\text { Maldonado- } \\
\text { Martín } \\
(2017)\end{array}$ & Spain & $\begin{array}{l}\text { NYHA } \\
\text { class } \\
\text { II- III } \\
\text { LVEF > } \\
50 \%\end{array}$ & $\begin{array}{l}\text { Total patients: } n=47,6 \\
\text { males/41 females } \\
\text { G1: } n=23 \text {, mean age (SD): } \\
67.5(5.9) \\
\text { G2: } n=24 \text {, mean age (SD): } \\
65.6(4.8)\end{array}$ & $\begin{array}{l}\text { G1: Endurance training } \\
\text { G2: Attention control } \\
\text { group }\end{array}$ & $\begin{array}{l}\text { Three times per week for } \\
16 \text { weeks }\end{array}$ & $6 \mathrm{MWT}$, peak $\mathrm{VO}_{2}$ \\
\hline $\begin{array}{l}\text { Kitzman } \\
(2016)\end{array}$ & USA & $\begin{array}{l}\text { NYHA } \\
\text { class } \\
\text { II-III } \\
\text { LVEF > } \\
50 \%\end{array}$ & $\begin{array}{l}\text { Total patients: } n=100 \\
\text { G1: } n=51,10 \text { males } / 41 \\
\text { females, mean age (SD): } 66.9 \\
(5.5) \\
\text { G2: } n=49,9 \text { males } / 40 \\
\text { females, mean age (SD): } 66.0 \\
(4.8)\end{array}$ & $\begin{array}{l}\text { G1: Endurance training } \\
\text { G2: No intervention }\end{array}$ & $\begin{array}{l}\text { Three times per week for } \\
20 \text { weeks }\end{array}$ & $\begin{array}{l}\mathrm{E} / \mathrm{A}, \mathrm{E} / \mathrm{e}^{\prime}, \mathrm{e}^{\prime}, 6 \mathrm{MWT} \text {, } \\
\text { peak } \mathrm{VO}_{2}, \mathrm{VE} / \mathrm{VCO}_{2} \\
\text { slope }\end{array}$ \\
\hline $\begin{array}{l}\mathrm{Fu} \\
(2016)\end{array}$ & China & $\begin{array}{l}\text { NYHA } \\
\text { class } \\
\text { II-III } \\
\text { LVEF > } \\
50 \%\end{array}$ & $\begin{array}{l}\text { Total patients: } n=59 \\
\text { G1: } n=30,20 \text { males } / 10 \\
\text { females, mean age (SD): } 60.5 \\
(14.8) \\
\text { G2: } n=29,18 \text { males } / 11 \\
\text { females, mean age (SD): } 62.4 \\
(12.9)\end{array}$ & $\begin{array}{l}\text { G1: Endurance training } \\
\text { G2: General health care }\end{array}$ & $\begin{array}{l}\text { Three sessions per week } \\
\text { for } 12 \text { weeks }\end{array}$ & $\begin{array}{l}\text { E/A, E/e', QoL, peak } \\
\mathrm{VO}_{2}, \mathrm{VE} / \mathrm{VCO}_{2} \text { slope, } \\
\mathrm{A}-\mathrm{VO}_{2} \text { Diff }\end{array}$ \\
\hline $\begin{array}{l}\text { Nolte } \\
(2015)\end{array}$ & Germany & $\begin{array}{l}\text { NYHA } \\
\text { class } \\
\text { II-III } \\
\text { LVEF > } \\
50 \%\end{array}$ & $\begin{array}{l}\text { Total patients: } n=64 \\
\text { G1: } n=44,20 \text { males } / 24 \\
\text { females, mean age (SD): } 64 \text { (8) } \\
\text { G2: } n=20,8 \text { males } / 12 \\
\text { females, mean age (SD): } 65 \text { (6) }\end{array}$ & $\begin{array}{l}\text { G1: A combination of } \\
\text { endurance and } \\
\text { resistance training } \\
\text { G2: Usual care }\end{array}$ & $\begin{array}{l}\text { Weeks 1-4: endurance } \\
\text { training two times per } \\
\text { week } \\
\text { From week } 5 \text { onward: } \\
\text { endurance training three } \\
\text { times per week } \\
\text { Resistance training two } \\
\text { times per week }\end{array}$ & $\mathrm{E} / \mathrm{A}, \mathrm{VE} / \mathrm{VCO}_{2}$ slope \\
\hline $\begin{array}{l}\text { Karavidas } \\
\text { (2013) }\end{array}$ & Greece & $\begin{array}{l}\text { NYHA } \\
\text { class } \\
\text { II-III } \\
\text { LVEF > } \\
50 \%\end{array}$ & $\begin{array}{l}\text { Total patients: } n=30 \\
\text { G1: } n=15,6 \text { males } / 9 \text { females, } \\
\text { mean age (SD): } 69.4(8.6) \\
\text { G2: } n=15,6 \text { males } / 9 \text { females, } \\
\text { mean age (SD): } 68.5(7.9)\end{array}$ & $\begin{array}{l}\text { G1: FES } \\
\text { G2: A placebo training }\end{array}$ & $\begin{array}{l}\text { Five times per week for } 6 \\
\text { weeks }\end{array}$ & E/A, E/e', QoL, 6MWT, \\
\hline $\begin{array}{l}\text { Kitzman } \\
\text { (2013) }\end{array}$ & USA & $\begin{array}{l}\text { NYHA } \\
\text { class } \\
\text { II- III }\end{array}$ & Total patients: $n=63$ & $\begin{array}{l}\text { G1: Endurance training } \\
\text { G2: Attention control }\end{array}$ & $\begin{array}{l}\text { Three times per week for } \\
16 \text { weeks }\end{array}$ & $\begin{array}{l}\text { E/A, QoL, } 6 \mathrm{MWT} \text {, peak } \\
\mathrm{VO}_{2}, \mathrm{VE} / \mathrm{VCO}_{2} \text { slope }\end{array}$ \\
\hline
\end{tabular}

Page 9/16 


\begin{tabular}{|c|c|c|c|c|c|c|}
\hline & & $\begin{array}{l}\text { LVEF > } \\
50 \%\end{array}$ & $\begin{array}{l}\text { G1: } n=32,72 \% \text { females, mean } \\
\text { age (SD): } 70(7) \\
\text { G2: } n=31,80 \% \text { females, mean } \\
\text { age (SD): } 70(7)\end{array}$ & & & \\
\hline $\begin{array}{l}\text { Palau } \\
\text { (2013) }\end{array}$ & Spain & $\begin{array}{l}\text { NYHA } \\
\text { class I- } \\
\text { IV } \\
\text { LVEF > } \\
50 \%\end{array}$ & $\begin{array}{l}\text { Total patients: } \mathrm{n}=26 \\
\mathrm{G} 1: \mathrm{n}=14,7 \text { males } / 7 \text { females, } \\
\text { mean age }(\mathrm{SD}): 68(13) \\
\mathrm{G} 2: \mathrm{n}=12,6 \mathrm{males} / 6 \text { females, } \\
\text { mean age }(\mathrm{SD}): 74(3)\end{array}$ & $\begin{array}{l}\text { G1: IMT } \\
\text { G2: No intervention }\end{array}$ & $\begin{array}{l}\text { Two sessions per week for } \\
12 \text { weeks }\end{array}$ & E/e', e', QoL, 6MWT \\
\hline $\begin{array}{l}\text { Smart } \\
(2012)\end{array}$ & Australia & $\begin{array}{l}\text { NYHA } \\
\text { class I- } \\
\text { II } \\
\text { LVEF > } \\
50 \%\end{array}$ & $\begin{array}{l}\text { Total patients: } n=25 \\
\text { G1: } n=12,7 \text { males } / 5 \text { females, } \\
\text { mean age (SD): } 68(11) \\
\text { G2: } n=13,6 \text { males } / 7 \text { females, } \\
\text { mean age (SD): } 65(6)\end{array}$ & $\begin{array}{l}\text { G1: Endurance training } \\
\text { G2: Sedentary control } \\
\text { group }\end{array}$ & $\begin{array}{l}\text { Three times per week for } \\
16 \text { weeks }\end{array}$ & $\begin{array}{l}\text { E/A, E/e', e', QoL, peak } \\
\mathrm{VO}_{2}, \mathrm{VE} / \mathrm{VCO}_{2} \text { slope }\end{array}$ \\
\hline $\begin{array}{l}\text { Haykowsky } \\
\text { (2012) }\end{array}$ & USA & $\begin{array}{l}\text { NYHA } \\
\text { class } \\
\text { II- III }\end{array}$ & $\begin{array}{l}\text { Total patients: } n=40 \\
\text { G1: } n=22,4 \text { males } / 18 \\
\text { females, mean age (SD): } 70 \text { (6) } \\
\text { G2: } n=18,1 \text { males } / 17 \\
\text { females, mean age (SD): } 68 \text { (5) }\end{array}$ & $\begin{array}{l}\text { G1: Endurance training } \\
\text { G2: Attention control } \\
\text { group }\end{array}$ & $\begin{array}{l}\text { Three times per week for } \\
16 \text { weeks }\end{array}$ & Peak $\mathrm{VO}_{2}, \mathrm{~A} \mathrm{VO}_{2}$ Diff \\
\hline $\begin{array}{l}\text { Alves } \\
(2012)\end{array}$ & Portugal & $\begin{array}{l}\text { NYHA } \\
\text { class } \\
\text { I-III } \\
\text { LVEF > } \\
50 \%\end{array}$ & $\begin{array}{l}\text { Total patients: } \mathrm{n}=31,22 \\
\text { males } / 9 \text { females, mean age } \\
(\mathrm{SD}): 62.9(10.2) \\
\mathrm{G} 1: \mathrm{n}=20 \\
\text { G2: } \mathrm{n}=11\end{array}$ & $\begin{array}{l}\text { G1: Endurance training } \\
\text { G2: No intervention }\end{array}$ & $\begin{array}{l}\text { Three times per week for } \\
24 \text { weeks }\end{array}$ & $E / A$ \\
\hline $\begin{array}{l}\text { Edelmann } \\
\text { (2011) }\end{array}$ & Germany & $\begin{array}{l}\text { NYHA } \\
\text { class } \\
\text { II-III } \\
\text { LVEF > } \\
50 \%\end{array}$ & $\begin{array}{l}\text { Total patients: } n=64 \\
\text { G1: } n=44,20 \text { males/24 } \\
\text { females, mean age (SD): } 64 \text { (8) } \\
\text { G2: } n=20,8 \text { males } / 12 \\
\text { females, mean age (SD): } 65 \text { (6) }\end{array}$ & $\begin{array}{l}\text { G1: A combination of } \\
\text { endurance and } \\
\text { resistance training } \\
\text { G2: Usual care }\end{array}$ & $\begin{array}{l}\text { Weeks 1-4: endurance } \\
\text { training two times per } \\
\text { week } \\
\text { From week } 5 \text { onward: } \\
\text { endurance training three } \\
\text { times per week } \\
\text { Resistance training two } \\
\text { times per week }\end{array}$ & $\begin{array}{l}\text { E/e', e', QoL, 6MWT, } \\
\text { peak VO } \\
2\end{array}$ \\
\hline $\begin{array}{l}\text { Kitzman } \\
(2010)\end{array}$ & USA & $\begin{array}{l}\text { NYHA } \\
\text { class } \\
\text { II- III } \\
\text { LVEF > } \\
50 \%\end{array}$ & $\begin{array}{l}\text { Total patients: } n=53 \\
\text { G1: } n=26,6 \text { males } / 20 \\
\text { females, mean age (SD): } 70 \text { (6) } \\
\text { G2: } n=27,7 \text { males } / 20 \\
\text { females, mean age (SD): } 69 \text { (5) }\end{array}$ & $\begin{array}{l}\text { G1هEndurance training } \\
\text { G2: Attention control } \\
\text { group }\end{array}$ & $\begin{array}{l}\text { Three times per week for } \\
16 \text { weeks }\end{array}$ & $\begin{array}{l}\text { E/A, QoL, } 6 \mathrm{MWT} \text {, peak } \\
\mathrm{VO}_{2}, \mathrm{VE} / \mathrm{VCO}_{2} \text { slope }\end{array}$ \\
\hline $\begin{array}{l}\text { Gary } \\
(2004)\end{array}$ & USA & $\begin{array}{l}\text { NYHA } \\
\text { class } \\
\text { II- III } \\
\text { LVEF > } \\
50 \%\end{array}$ & $\begin{array}{l}\text { Total patients: } n=28 \\
\text { G1: } n=15,15 \text { females, mean } \\
\text { age (SD): } 67(11) \\
\text { G2: } n=13,13 \text { females, mean } \\
\text { age (SD): } 69(11)\end{array}$ & $\begin{array}{l}\text { G1: Endurance training } \\
\text { G2: Control group }\end{array}$ & $\begin{array}{l}\text { Three sessions per week } \\
\text { for } 12 \text { weeks }\end{array}$ & QoL, 6MWT \\
\hline
\end{tabular}

NYHA: New York Heart Association 
Table 2

Risks of bias among the included studies

\begin{tabular}{|c|c|c|c|c|c|c|c|c|c|c|c|}
\hline $\begin{array}{l}\text { Article, } \\
\text { year }\end{array}$ & $\begin{array}{l}\text { Eligibility } \\
\text { criteria }\end{array}$ & $\begin{array}{l}\text { Random } \\
\text { allocation }\end{array}$ & $\begin{array}{l}\text { Concealed } \\
\text { allocation }\end{array}$ & $\begin{array}{l}\text { Baseline } \\
\text { comparability }\end{array}$ & $\begin{array}{l}\text { Blind } \\
\text { subjects }\end{array}$ & $\begin{array}{l}\text { Blind } \\
\text { therapists }\end{array}$ & $\begin{array}{l}\text { Blind } \\
\text { assessors }\end{array}$ & $\begin{array}{l}\text { Adequate } \\
\text { follow-up }\end{array}$ & $\begin{array}{l}\text { Intention } \\
\text { to treat } \\
\text { analysis }\end{array}$ & $\begin{array}{l}\text { Between- } \\
\text { group } \\
\text { comparisons }\end{array}$ & $\begin{array}{l}\text { Poil } \\
\text { esti } \\
\text { and } \\
\text { vari }\end{array}$ \\
\hline $\begin{array}{l}\text { Palau } \\
(2019)\end{array}$ & YES & YES & NO & YES & NO & YES & YES & YES & NO & YES & YES \\
\hline $\begin{array}{l}\text { Maldonado- } \\
\text { Martín } \\
\text { (2017) }\end{array}$ & YES & YES & NO & YES & NO & YES & NO & YES & NO & YES & YES \\
\hline $\begin{array}{l}\text { Kitzman } \\
(2016)\end{array}$ & YES & YES & NO & YES & NO & YES & NO & YES & YES & YES & YES \\
\hline $\begin{array}{l}\text { Fu } \\
(2016)\end{array}$ & YES & NO & NO & YES & NO & NO & NO & YES & NO & YES & YES \\
\hline $\begin{array}{l}\text { Nolte } \\
(2015)\end{array}$ & YES & YES & NO & YES & NO & NO & NO & YES & NO & YES & YES \\
\hline $\begin{array}{l}\text { Karavidas } \\
\text { (2013) }\end{array}$ & YES & YES & NO & YES & NO & NO & YES & YES & NO & YES & YES \\
\hline $\begin{array}{l}\text { Kitzman } \\
(2013)\end{array}$ & YES & YES & NO & YES & NO & NO & YES & YES & YES & YES & YES \\
\hline $\begin{array}{l}\text { Palau } \\
(2013)\end{array}$ & YES & YES & NO & YES & NO & NO & NO & YES & YES & YES & YES \\
\hline $\begin{array}{l}\text { Haykowsky } \\
(2012)\end{array}$ & YES & YES & NO & YES & NO & YES & NO & YES & YES & YES & YES \\
\hline $\begin{array}{l}\text { Alves } \\
(2012)\end{array}$ & YES & YES & NO & YES & NO & YES & NO & YES & YES & YES & YES \\
\hline $\begin{array}{l}\text { Smart } \\
(2012)\end{array}$ & YES & YES & NO & YES & NO & NO & NO & YES & YES & YES & YES \\
\hline $\begin{array}{l}\text { Edelmann } \\
\text { (2011) }\end{array}$ & YES & YES & NO & YES & NO & NO & NO & YES & NO & YES & YES \\
\hline $\begin{array}{l}\text { Kitzman } \\
(2010)\end{array}$ & YES & YES & NO & YES & NO & NO & YES & YES & YES & YES & YES \\
\hline $\begin{array}{l}\text { Gary } \\
(2004)\end{array}$ & YES & YES & NO & YES & NO & NO & NO & YES & NO & YES & YES \\
\hline
\end{tabular}

\section{Figures}




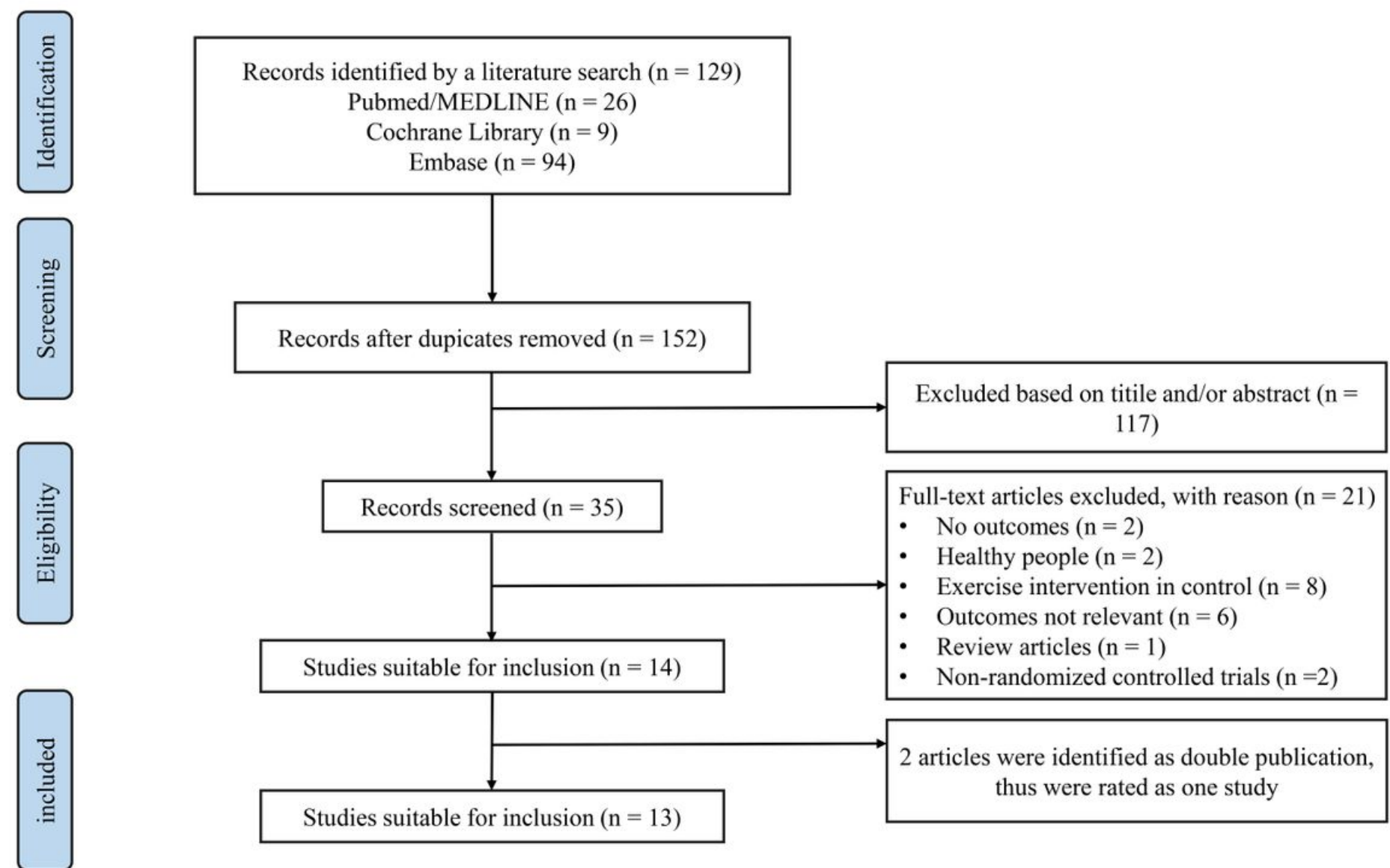

Figure 1

Flow chart of the study selection procedure. 

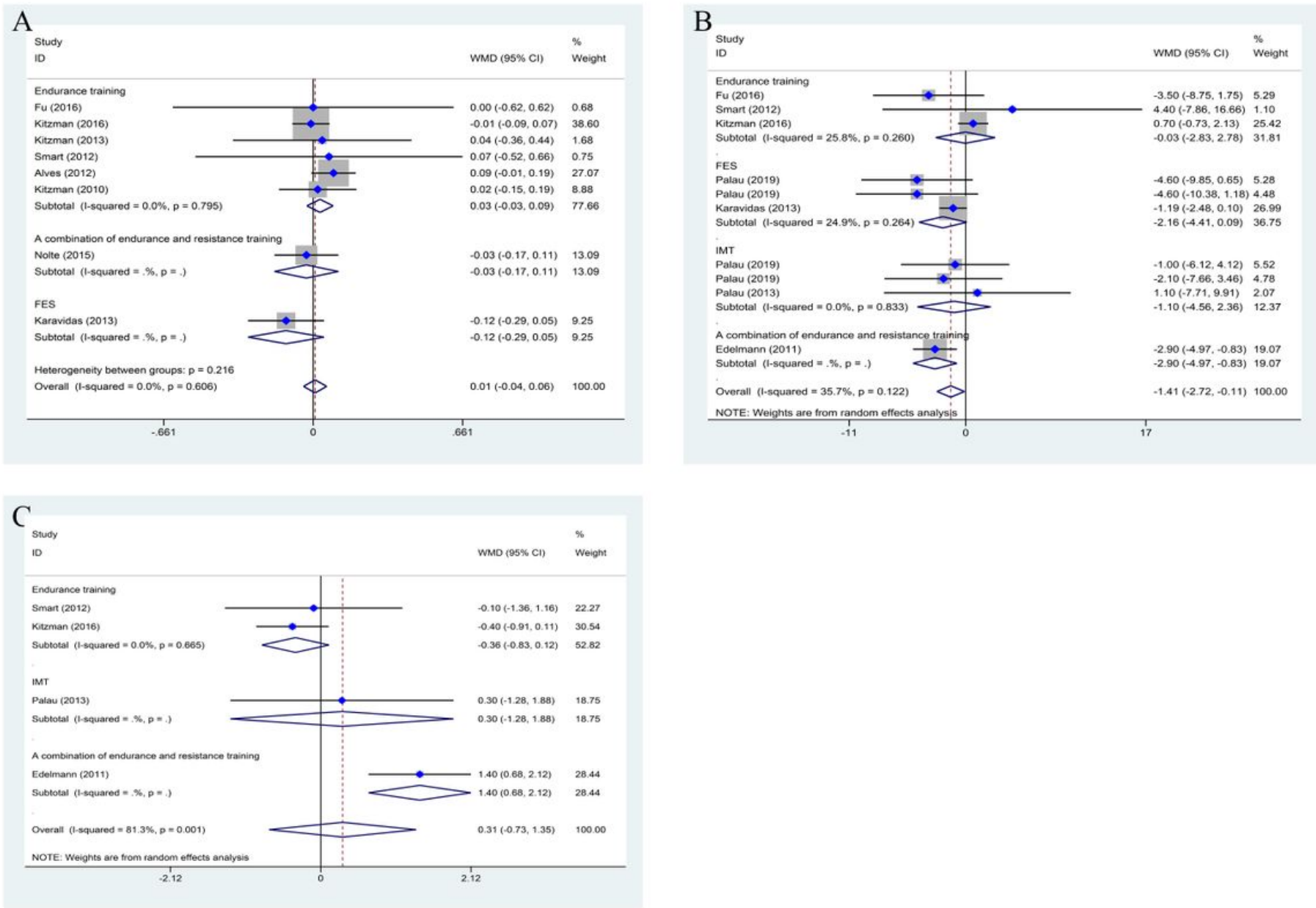

\section{Figure 2}

Forest plot showing the effects of exercise and physiotherapy on diastolic function: the ratio of peak early to late diastolic mitral inflow velocities (E/A; $A$ ), change in the ratio of early diastolic mitral inflow to annular velocities ( $\left.E / E^{\prime} ; B\right)$, the early diastolic mitral annular velocity (e'; C). 
Endurance training Fu (2016) Kitzman (2013)

Smart (2012)

Kitzman (2010)

Gary (2004)

Kitzman (2016)

Subtotal (I-squared $=57.5 \%, p=0.038$ )

FES

Palau (2019)

Palau (2019)

Karavidas (2013)

Subtotal $(\mathrm{I}$-squared $=1.4 \%$,

IMT

Palau (2019)

Palau (2019)

Palau (2013)

Subtotal (I-squared $=0.0 \%, p=0.745$ )

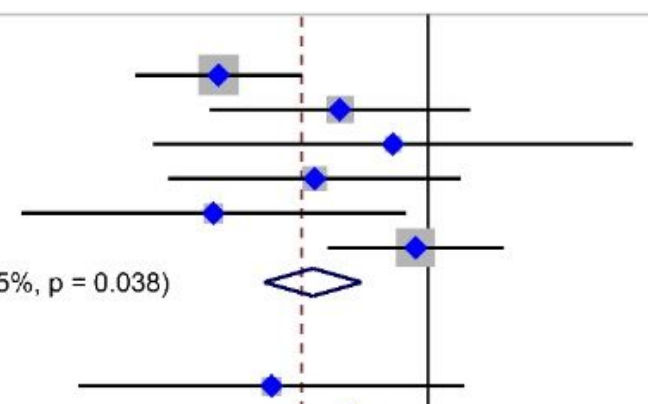

WMD $(95 \% \mathrm{Cl})$

Weight

$-16.60(-23.19,-10.01) \quad 21.27$

$-7.00(-17.30,3.30) \quad 8.72$

$-2.80(-21.77,16.17) \quad 2.57$

$-9.00(-20.59,2.59) \quad 6.88$

$-17.00(-32.24,-1.76) \quad 3.98$

$-1.00(-7.98,5.98) \quad 18.99$

$-9.13(-12.98,-5.28) \quad 62.42$

$-12.40(-27.67,2.87) \quad 3.97$

$-6.20(-22.12,9.72) \quad 3.65$

$-19.70(-30.35,-9.05) \quad 8.16$

$-14.74(-22.40,-7.08) \quad 15.77$

$-14.30(-28.48,-0.12) \quad 4.60$

$-12.70(-26.98,1.58) \quad 4.53$

$-6.10(-22.57,10.37) \quad 3.41$

$-11.49(-20.08,-2.91) \quad 12.55$

A combination of endurance and resistance training

Edelmann (2011)

Subtotal (I-squared $=. \%, p=$.)

Heterogeneity between groups: $p=0.494$

Overall (I-squared $=28.5 \%, p=0.158$ )

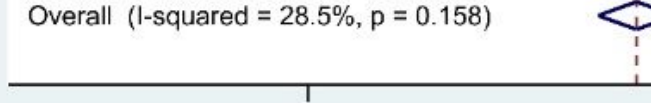

$\begin{array}{lll}1 & 1 & 1 \\ -36 & 0 & 18\end{array}$

$-6.00(-15.99,3.99) \quad 9.26$

$-6.00(-15.99,3.99) \quad 9.26$

$-10.02(-13.06,-6.98) \quad 100.00$

\section{Figure 3}

Forest plot showing the effects of exercise and physiotherapy on Minnesota Living With Heart Failure Questionnaire (MLHFQ) total score. 

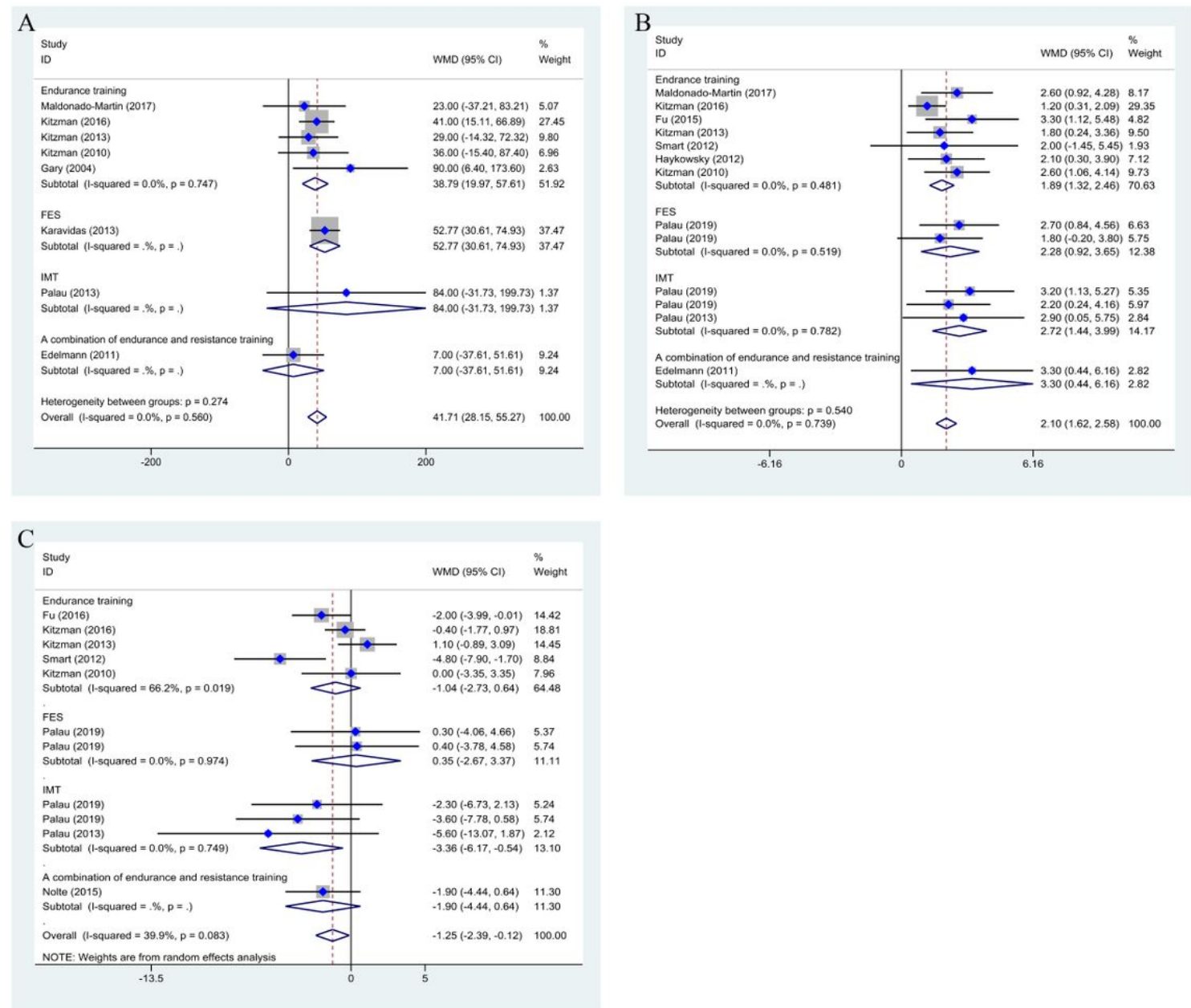

\section{Figure 4}

Forest plot showing the effects of exercise and physiotherapy on exercise performance: 6-minute walk test (6MWT; A), change in peak oxygen consumption (peak VO2; B), ventilation/carbon dioxide ratio slope (VE/VCO2 slope; C) 


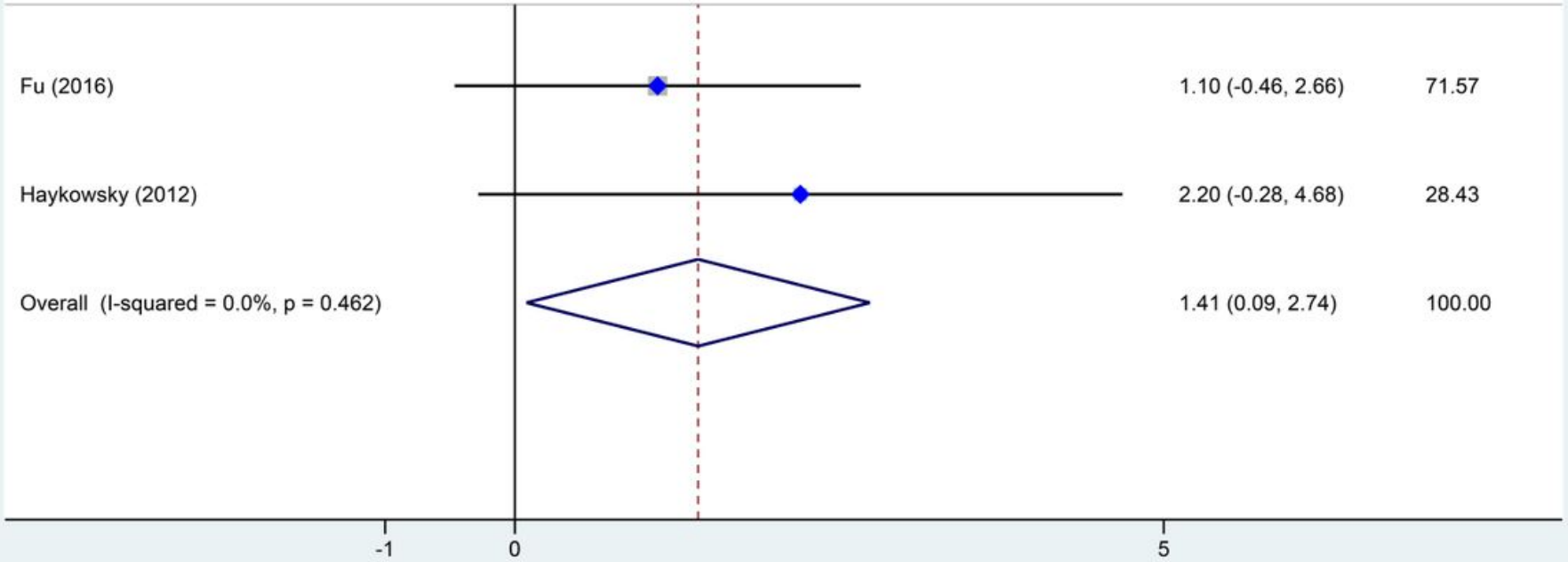

Figure 5

Forest plot showing the effects of endurance training on arterial-venous oxygen difference (A-VO2 Diff) 